\title{
The Book on Life Beyond by Bô Yin Râ: Death and Afterlife in Spiritual Perspective
}

\author{
Bodo Reichenbach \\ Department of Modern Foreign Languages and Literatures \\ Boston University
}

\begin{abstract}
This paper seeks to draw attention to a comprehensive work on death-related questions, first published in 1920, that sheds light on crucial problems still discussed today. The author speaks from his extensive observations of the dying process and near-death phenomena, seen from a spiritual point of view, but, more importantly, discusses the inherent structure of nonphysical existence, where life no longer is perceived by mortal senses but rather, as he states, by virtue of a spiritual organism and its faculties. The book explains near-death experiences as subjective glimpses of the life to come, apprehended through a person's timeless senses, which normally lie dormant during earthly life but reawaken at the point of separation from the body. The book describes nonphysical reality as composed of infinite dimensions and especially describes the sphere of phantom worlds, born and sustained by misdirected human faith, which man encounters first when he arrives beyond. These pseudo heavens are shown to be a serious threat to those arriving unprepared and uninformed. The book dismisses all occult phenomena as being purely physical in nature and, therefore, lacking value as evidence for afterlife.
\end{abstract}

The following discussion of Bô Yin Râ's ${ }^{1}$ Das Buch vom Jenseits $(1920,1929),{ }^{2}$ contributed by the translator of its first English edition (1978), seeks to acquaint the readers of Anabiosis with an informative work by an author who is not yet widely known in English-speaking countries. His forty books, published in German between 1919 and 1939, present a comprehensive exposition of physical and spiritual realities, containing answers to many crucial problems in religion, ethics, and psychology.

Especially relevant in the present context is The Book on Life Beyond (1978), which was written to provide the reader with what the author sees as the essential facts about the states of afterlife one can expect to find the moment this present life comes to an end. The book means to prepare the reader in the way a traveler's guidebook tells about an unknown land, which some day everyone will have to enter, whether or not he is prepared. But one who knows what lies ahead is able to approach the life to come without anxiety and 
superstition. The book differs significantly from other studies of the subject in that the author places mortal life within a wider, metaphysical context and writes that physical existence is but a brief, if highly consequential, fragment of every person's timeless evolution.

The author states his aim is not to prove nor argue that the afterlife exists, nor to persuade any reader who prefers to hold the opposite view. In his view it is vain to search for valid scientific proof, verifiable by instruments, because the only proof there is, or ever can be, lies in each person's own experience, gained either during mortal life or after it has ended. His book is meant not for those who want proof, but for those who want useful information (based on the author's experiences) about the nature of that future life, its laws and inner structure, and the place the human being occupies within that life.

According to the author, The Book on Life Beyond presents objective, accurate accounts of the afterlife, based on many years of observation and experience. Besides describing man's condition in the life to come, the author offers practical advice on how this present life may serve a person to prepare for the continuation of his life in spiritual form, lest he one day find himself upon the other shore bewildered and confused, and in this helpless state drift aimlessly between mirages, until he finally becomes entrapped, perhaps for ages, by the immensely powerful attractions of some collectively engendered phantom "heaven."

To conclude these preliminary remarks, one should add a comment on the difficulty, indeed impossibility, of assigning to this author any fitting place within historical traditions of religion, philosophy, or mysticism; for neither as a person nor as a writer does he belong to any of these systems. Recognizing, in his expositions, certain elements that one may also find in other places, a reader might assume that what this author has to say is, possibly, no more than yet another syncretistic motley of derived ideas. According to the author, however, his knowledge of spiritual realities was not learned from books or other people, nor gained by any mental effort, but is the fruit of personal, immediate experience. Occasional agreements between his expositions and particular religious or philosophical beliefs will, therefore, naturally result wherever such beliefs reflect some aspect of concrete reality. On balance, however, the few such similarities are less significant than the substantial differences between this author's presentations and other worldviews.

Here, then, are the main points covered in The Book on Life Beyond. According to the author, the act of dying is simply the 
transition that irrevocably separates a person's spiritual organism, and the latter's consciousness - which had lairı mostly dormant during mortal life - from its no longer serviceable physical body. Following this separation, which takes only a few moments, the person finds himself at once awake and conscious in his timeless organism, in which he had already been alive eternities before his "incarnation" in material form. The spiritual body, whose substance is a radiant form of energy, is indestructible, but in most persons it is arrested in a state of only rudimentary development. This organism is now a person's only means of taking part in any form of spiritual existence.

According to the author, man's mortal life is but a fateful interlude in his continued spiritual life: a fall from the domain of light, his origin and final home, which he himself abandoned by an act of will and longs to find again as soon as he begins to sense his situation. Human "life," then, includes aeons of physical existence both before and after. And this, in effect, is an abnormal, wholly foreign state for man, in that he is by origin and nature a purely spiritual being.

From this it also follows that the life man will resume once he is freed from his physical body is not a different reality somewhere above the clouds - because his consciousness, identity, inner development, and his place within the universe all remain entirely unchanged - but rather a new way of being alive, a new form of perceiving what is still the very same reality owing to the senses of a different organism. As Bô Yin Râ explains, in life beyond we continue to experience the very life we lived on earth, only now we sense that life from, as it were, "the other side." Given that the spiritual faculties, which man must learn to use in life beyond, are already present in his mortal state, he can begin to use them also here on earth and thus become a spiritually conscious individual. Except for those specific, spiritual faculties, man is no more than any other animal. Even his apparently "higher" state of evolution is only due to these inherent, if inactive, energies that also influence the mortal psyche and which other creatures have as well as man.

During near-death experiences a person's spiritual senses are temporarily awakened, and he may perceive a glimpse of life beyond by virtue of this different organism. Natural consequences of such experiences are the loss of fear of dying and a thorough change in attitude toward life, both here and in the form to come.

Given that both forms of life are only two perspectives of the same reality, it should not be surprising that there are many similarities between the things we do and apprehend on earth and those we 
shall experience on the other side. Bô Yin Râ relates that in the spiritual worlds not only are there equivalents of everything we find in nature - including mountain ranges, forests, rivers, lakes, and seas - but that, indeed, the nature we perceive is but a flawed and dark reflection of the reality one apprehends in spiritual perception, the realm in which reside the timeless patterns, in ultimate perfection, for everything we know on earth. Bô Yin Râ's descriptions of these worlds have striking implications for a new approach to certain concepts found in Plato's thought and may also shed light on mythology, utopias, and cities of God. Of particular interest would seem the author's reference to a radiant spiritual Temple - situated on a soaring mountain, surrounded by flowering gardens in the midst of snow and ice - of which all sacred structures here on earth are modified reflections, intuitively sensed by gifted artists.

In view of the relationship between the world of matter (the realm of mere effects) and the dimension of the spirit (the sphere of primary causes), the ancient concept of "creation" appears in a very different light. For, as the author states, the whole material universe with its unnumbered galaxies, forming and dissolving endlessly in time and space, was not "created out of nothing" by some omnipotent Maker nor by a random cataclysm originating in the sphere of matter. Rather, it has existence, without beginning or end, as a result of being an immediate reflex, directly manifesting in material form, of an impulse generated in the spiritual domain, which is the sphere of causes. Like the world of spirit, therefore, the physical universe as a whole is a timeless aspect of reality, and even though at every moment galaxies are born and die in time and space, the universe as such endures forever.

Unlike the physical world, however, which we perceive as a threedimensional continuum, the spiritual domain, according to the author, has infinite dimensions. All these interpenetrate one another, that is to say, they occupy the same location within space. The various dimensions are not, however, simultaneously perceived by those who occupy one or the other even though the spirit's substance, and the worlds engendered by that substance, permeate each particle of physical matter.

A valuable contribution to a fuller understanding of the inner structure of our physical reality, including all "occult" phenomena, is Bô Yin Râ's point that physical reality embraces a far wider range of energies, including conscious beings, than we can apprehend by means of our limited five senses, which in man are even less developed than they are in certain animals. In other words, we only 
apprehend a tiny fragment even of physical reality, by far the larger part of which is simply hidden from our senses. This to us "invisible" - but purely physical - dimension of our present world is the domain of the "occult," which mediums and clairvoyants may at times perceive, erroneously assuming that they have seen spiritual reality. The occult sphere is, furthermore, inhabited by certain conscious, leech-like creatures, which are the real authors of all genuine phenomena of the occult. These parasites feed on the psychic substance of the "medium" and ultimately will destroy the soul and mind of their unwitting hosts, according to Bô Yin Râ. Most "occult" phenomena do not involve these creatures but are simply harmless fraud. Given, however, that the occult sphere is merely a still unknown region of physical nature, while those who leave the earth leave also its invisible domain, it will be obvious that the participants in a "séance" do not commune with any human soul or spirit (all of whom are safe from being summoned to perform some trivial experiment for the amusement of the curious). At the most, they experience these deceptive creatures, which gladly masquerade as some departed mortal.

The author also describes in some detail the initial experiences of those arriving on the other side of life. Typically, their first reaction is complete surprise at something wholly unexpected, a state for which they were not in the least prepared. In their confusion they drift aimlessly along the borders of the unknown land in which they find themselves, and since they are unable to distinguish help from danger, they shy away from those who would assist them. For, as the author indicates, spiritual helpers are at all times present and ready to give guidance to anyone who would discover the interior of the spirit's land and begin ascending its majestic heights. Most of the new arrivals, however, do not have such concerns; they are still too wrapped up in their accustomed earthly notions to comprehend their new environment. As the author points out, the mere transition from one kind of perception to another, i.e., from physical to spiritual experience, does not expand a person's knowledge or horizon, let alone endow him with spontaneous enlightenment. Instead, everyone awakens on the other side as exactly the same person he was on earth, governed by the same ideas, beliefs, and prejudices that moved him in his mortal life.

Thus, some people will expect to find a certain kind of heaven, or hell, and are perplexed when they do not encounter what they had envisioned. Clinging to their beliefs, however, they are blind to any kind of help. Some again are so conceited when they find they have 
attained "eternal life" that they now haughtily reject the guidance they are offered. Persons whose spiritual senses were not much developed during life often fail to recognize that they no longer occupy a physical body. Instead, they think, some "miracle" has cured them of their former illness, for clearly they do not feel "dead" but rather well and happy. In this condition the departed often try to show their relatives and friends, whom they see grieving over their now lifeless body, that their anguish is unnecessary. But the latter are so occupied with their emotions that they fail to sense what the departed want to tell them. Only when the person sees that he no longer can communicate with those around him does he finally discover the loss of his mortal organism.

Those, again, who were convinced that there is no such thing as the "afterlife" try to look upon their new condition as merely a continuation of their physical existence. People who were so immersed in earthly life that they had never given any thought to spiritual concerns face a time of desperation when they realize they cannot return to earthly life. Those, on the other hand, who had been absorbed here by some ambition, fixed idea, or mission very quickly lose all interest in the existence they left behind and only find a new way to pursue their aims within their changed environment.

All these individuals, Bô Yin Râ explains, will sooner or later find a state they regard as the fulfillment of their hopes and dreams: a paradise of their own making. They will be magnetically attracted to one of the innumerable phantom worlds in life beyond. The author calls them border realms, in that they are the lowest worlds in the life beyond, situated, as it were, at the periphery of spiritual reality and thus still very close to physical existence. The specific world to which a person will become attracted is the one in whose existence he had already participated during life on earth, and which thus corresponds to his ideas and expectations.

In this context the book relates that every impulse, wish, or thought that moves the human mind on earth produces an equivalent reaction also on the other side. There this creates a kindred phantom realm, a world that corresponds exactly to its maker's will, which continues to exist until the energies that brought it into being are neutralized or finally exhausted. Since these energies are constantly regenerated by human faith and will, the phantom worlds they sustain and manifest may well endure for aeons, measured in earthly terms. For all their indestructible nature, however, these worlds subsist in constant inner turmoil and are, besides, embroiled in endless conflicts with each other because the untold millions who 
collaborate in forming and sustaining these domains are in themselves, as individuals, still disunited and of many minds. Each person, thus, forever ruins what another builds.

Here the author draws attention to a startling phenomenon: namely, that such phantom worlds continuously influence events also on earth, simply by affecting the minds of susceptible mortals. According to the author, much of the religious hatred and intolerance, national hostilities, ideological fanaticism, and other forms of prejudice that have plagued mankind throughout history, are repercussions of the bitter feuds between opposing worlds beyond. The resulting strife on earth in turn intensifies the enmity between these border realms.

The various phantom worlds, collectively engendered and sustained by misdirected human will, are thus, according to Bô Yin Râ, the gravest peril facing human beings as they arrive beyond. For if a person is entrapped in such a world of self-imposed illusion, he loses sight of his predestined inner goal, perhaps for many ages. But even though these worlds may last for aeons, one day they are fated to disintegrate: as one by one the souls sustaining them awaken from their dreams and see their self-created heavens vanish. And then, profoundly shaken and distressed, ages wasted by their folly, they must begin once more to seek the path that, on a long and painful ascent, will take them to the realm of absolute reality, where ultimate fulfillment is no mere illusion.

To warn the reader of the fate of falling victim to such selfinduced illusion, and to describe the way he ought to go instead, is thus the foremost reason The Book on Life Beyond was written. On this point the author also states that he conveys not merely his own experiences in this book but also the insights of those guides and helpers who will come to man's assistance after his transition. Their help is made much easier, however, if a person is not wholly unprepared but has at least gone to the trouble of informing himself concerning some essential facts.

While the initial experiences of the departed are, according to the author, usually profound relief and joy, not all the realms beyond are forms of paradise. There are regions also of despair and darkness, of agony and harrowing remorse, which quite resemble the traditional ideas of hell. And in these spheres anyone, without exception, must make amends who in this life on earth had violated, by words and deeds against his fellow man, the all-sustaining harmony of spiritual law, whose inmost impulse, will, and nature is selfless love and infinite compassion. One who by his actions deliberately rejected 
being part of this reality, there must reap the fruits of his mistakes. Subjection to this fate is not, however, meted out as "punishment" by some offended, vengeful potentate who judges sinners at his pleasure, but, as the author stresses, a completely automatic consequence of having violated cosmic laws. For spiritual laws, he states, are in their operations no less neutral and inexorable - beyond even divine intervention - than are the laws of physical reality. Nonetheless, one who passes through these trying spheres there finds a chance to compensate for the disturbance he has caused. Still, from the fetters of this tragic state, which could so easily have been avoided, the human spirit cannot find release "until the uttermost farthing has been paid."

The author here especially discusses suicide as being a most grievous violation of the law in question, since by this act a person willfully destroys his earthly life, which he himself desired and finally attained by grace of spiritual law. But worse, by the destruction of his earthly form, man also loses the life and function of his timeless soul, without which there is no perception nor existence in the spirit's worlds. Suicide, then, instead of bringing liberation will only make man's lot still worse. Bô Yin Râ states that those who die by their own hand will finally have to endure another "incarnation," and this is one of the exceptional cases where a human spirit actually returns a second time. In the normal course, each spiritual entelechy lives only once in mortal form and then resumes its former timeless life.

Given that his mortal life is ultimately subject to the same reality whose timeless laws sustain the spirit's worlds, man's temporal aims and principles should not conflict with that reality, lest he injure or destroy himself. Some knowledge of these laws is, thus, essential if one would live one's life in harmony with the demands of what is ultimate reality. An important step in this direction, as one aspect of a scrupulously ethical life, is the cultivation of a proper attitude toward life beyond. For this the author's book provides invaluable information.

Human life, as he explains, is but the individuated emanation of one immeasurably vast, eternal unity, which manifests itself in countless hierarchies of individuated beings, all of whom comprise a single, undivided will and consciousness. The individuated human spirit cannot, however, find its final goal - salvation, liberation - so long as it is separated from this unity, as it is in mortal life, but only when it has once more become - in this life or the next - an integrated, conscious part of this reality.

By showing mortal life, and its transition to another form of 
being, from a spiritual perspective, The Book on Life Beyond provides good grounds for peace of mind and confidence; it dispels anxieties and misconceptions, and also tells the reader how he may himself determine, already in his present life, the course and progress of his life to come. And only one who has already found his "future" life - his timeless spiritual nature - here and now can truly ask: "O death, where is thy sting? O grave, where is thy victory?"

\section{NOTES}

1. Bô Yin Râ is the spiritual proper name of the German-born painter and author, Joseph Anton Schneiderfranken (1876-1943). See the chapter: Concerning My Name, in About My Books. Berkeley: The Kober Press, 1977. 13-20.

2. Das Buch vom Jenseits was first published in 1920 by Kurt Wolff's Verlag der Weissen Bücher in Munich. The second, enlarged edition appeared in 1929, in Basel \& Leipzig: Kobersche Verlagsbuchhandlung. The first English translation of this definitive edition is The Book on Life Beyond. San Francisco: The Kober Press, 1978. The book contains the chapters: The Art of Dying; The Temple of Eternity and the World of Spirit; The Only Absolute Reality; What Should One Do?

\section{A PARTIAL BIBLIOGRAPHY}

Bô Yin Râ. About My Books. Berkeley: Kober, 1977.

Bô Yin Râ. Das Buch des Trostes. Munich: Verlag der Weissen Bücher, 1924 ; (2nd ed.) Basel: Kober, 1948.

Bô Yin Râ. Das Buch vom Lebendigen Gott. Basel: Kober, 1927.

Bô Yin Râ. Hortus Conclusus. Basel: Kober, 1936.

Bô Yin Râ. The Book on Life Beyond. San Francisco: Kober, 1978.

Request for reprints to:

Bodo Reichenbach

23 Vista Circle

Arlington, Massachusetts 02174 
